IZA DP No. 2313

Lobbying Corruption and Political Influence

Nauro F. Campos

Francesco Giovannoni

September 2006 


\title{
Lobbying, Corruption and Political Influence
}

\author{
Nauro F. Campos \\ Brunel University, \\ CEPR and IZA Bonn \\ Francesco Giovannoni \\ CMPO, University of Bristol
}
Discussion Paper No. 2313
September 2006

\author{
IZA \\ P.O. Box 7240 \\ 53072 Bonn \\ Germany \\ Phone: +49-228-3894-0 \\ Fax: +49-228-3894-180 \\ Email: iza@iza.org
}

\begin{abstract}
Any opinions expressed here are those of the author(s) and not those of the institute. Research disseminated by IZA may include views on policy, but the institute itself takes no institutional policy positions.

The Institute for the Study of Labor (IZA) in Bonn is a local and virtual international research center and a place of communication between science, politics and business. IZA is an independent nonprofit company supported by Deutsche Post World Net. The center is associated with the University of Bonn and offers a stimulating research environment through its research networks, research support, and visitors and doctoral programs. IZA engages in (i) original and internationally competitive research in all fields of labor economics, (ii) development of policy concepts, and (iii) dissemination of research results and concepts to the interested public.
\end{abstract}

IZA Discussion Papers often represent preliminary work and are circulated to encourage discussion. Citation of such a paper should account for its provisional character. A revised version may be available directly from the author. 
IZA Discussion Paper No. 2313

September 2006

\section{ABSTRACT}

\section{Lobbying, Corruption and Political Influence*}

Conventional wisdom suggests that lobbying is the preferred mean for exerting political influence in rich countries and corruption the preferred one in poor countries. Analyses of their joint effects are understandably rare. This paper provides a theoretical framework that focus on the relationship between lobbying and corruption (that is, it investigates under what conditions they are complements or substitutes). The paper also offers novel econometric evidence on lobbying, corruption and influence using data for about 4000 firms in 25 transition countries. Our results show that (a) lobbying and corruption are substitutes, if anything; (b) firm size, age, ownership, per capita GDP and political stability are important determinants of lobby membership; and (c) lobbying seems to be a much more effective instrument for political influence than corruption, even in poorer, less developed countries.

JEL Classification: $\quad$ E23, D72, H26, O17, P16

Keywords: lobbying, corruption, transition, institutions

Corresponding author:

Nauro F. Campos

Department of Economics and Finance

Brunel University

Uxbridge, Middlesex UB8 3PH

United Kingdom

E-mail: Nauro.Campos@brunel.ac.uk

\footnotetext{
* We thank Toke Aidt, Laszlo Bruszt, Gérard Duchêne, Timothy Frye, Bard Harstad, Elisabetta lossa, Mathilde Maurel, Branko Milanovic, Boris Najman, Richard Pomfret, Jakob Svensson, John Wildman, an anonymous referee and seminar participants at Brunel and Paris 1 Sorbonne Universities and at the 2006 European Economic Association Meetings in Vienna for valuable comments on earlier versions. The usual disclaimer applies.
} 


\section{Introduction}

What is the relationship between lobbying and corruption? In a general sense, both are ways of obtaining help from the public sector in exchange for some favor. Indeed one could argue that lobbying is just a special form of corruption focused on legislative bodies or some other rule-making agency. ${ }^{1}$ There are, however, several important differences. One first difference is that lobbying does not always take the form of bribes or even of campaign contributions. In many cases, lobbyists have expertise that politicians don't have and can influence politicians by strategically sharing this expertise with them (see Austen-Smith and Wright 1994 for an example). In other cases, lobbyists can influence politicians by providing endorsements or by threatening to provide voters with damaging information about them or their policies (Grossman and Helpman 1999 and 2001). These differences have received little attention in the theoretical literature: two exceptions are Bennedsen and Feldmann (2005) and Dahm and Porteiro (2004), who compare the choice of lobbying with monetary payments or bribing to the choice of strategic provision of information to politicians.

The fact that lobbying is mainly aimed at policy-making institutions rather than the bureaucracy brings up a second difference since legislatures both set the policies that lobbyists care about and the rules that make it either easier or more difficult to bribe. Thus, lobbying can be both an activity that makes bribing irrelevant if it succeeds in influencing policy and an activity that makes bribing easier if it succeeds in undermining law enforcement. In other words, lobbying can be a substitute for, or a complement to, corruption. These two alternative interpretations of lobbying as a substitute or a complement to bribes have been investigated by two recent papers by Harstad and Svensson (2005) and Damania et al. (2004) respectively.

\footnotetext{
${ }^{1}$ Much of the theoretical literature on lobbying seems to adopt this position. In many models, e.g. Grossman and Helpman (2001), lobbying is modeled as monetary transfers from lobbyists to politicians and these transfers could equally be interpreted as campaign contributions or bribes. See Coate and Morris (1999) or Yalcin and Damania (2005) for examples of the latter interpretation.
} 
In this paper, we focus on this distinction and bring some empirical evidence to bear on the issue. ${ }^{2}$ Although the literature on lobbying is large and growing, the attendant empirical evidence is scarce, mostly limited to developed countries and either focuses on firm characteristics (e.g., size and sector) as main determinant of lobbying within a specific country or on macroeconomic variables such as per-capita GDP in cross-country comparisons. ${ }^{3}$ Here instead, we investigate lobbying, corruption and influence by examining firm characteristics as well as institutional features of the countries in which these firms operate. One advantage of focusing on the transition countries is that they provide an almost natural experiment setting in the sense that they started out with similar political institutions but implemented different economic and political reforms. Focusing on this set of countries is also important because they are often perceived to be among the most corrupt in the world (Kaufman et al., 1999) and are therefore countries in which few analysts would expect that lobbying would be able to play an important role.

Our analysis focus on two main questions: (a) what are the factors that determine the likelihood of a firm being a member of a lobby group? And (b) what is the relative role of corruption and lobby membership in explaining the probability of a firm seeing itself as influential vis-à-vis government laws, regulations and policies? Using 1999 survey data for 3,954 firms in 25 transition economies, our results show that, in addition to the factors highlighted in the literature, there is substantial evidence that lobbying and corruption are substitutes. That is, lobbying is an important alternative instrument of influence to corruption in transition countries. Our analysis also suggests that political institutions have a significant effect on lobbying. In particular, we find that lobbying is more likely to occur in parliamentary systems and in systems that enjoy high levels of political stability. Finally, we examine the relative effects of lobbying and corruption in terms of the production of political

\footnotetext{
${ }^{2}$ A third important distinction between lobbying and corruption is that the latter is often illegal.

${ }^{3}$ Examples of these empirical literatures are Mitra et al. (2002) and Bischof (2003), respectively.
} 
influence. First, we find that although lobbying is jointly determined with influence, corruption is not. Second, we find that the effect of lobbying on influence is always statistically significant, while that on corruption seldom is (independently of how we measure the latter). And third, and most importantly, we find that the size of the effect of lobbying is much larger than that of corruption. These findings support the notion that lobbying seems to be a considerably more effective way for firms to exert political influence than corruption. In this light, we argue that future research will do well in paying attention to lobbying activities when researching corruption as a competing medium of influence in poor countries.

The rest of the paper is structured as follows. In section two, we articulate more precisely the theoretical underpinnings of our empirical analysis. In section three, we describe the data and our empirical methodology while in section four we discuss our econometric results. Section five concludes.

\section{Theoretical framework}

Corruption and lobbying have been extensively analyzed in the literature. ${ }^{4}$ However, while these are clearly related phenomena, there have been very few attempts to investigate the relationship between them and the two literatures are quite distinct. One significant exception is recent work by Harstad and Svensson (2005). In their model, firms can gain influence by lobbying politicians or by bribing bureaucrats. The difference is that with lobbying, firms can get politicians to change the rules to their advantage while by bribing bureaucrats firms can only hope to stop the latter from enforcing the rules. Thus, in this framework, corruption and lobbying are substitutes. The first key assumption in the paper is that while bureaucrats who take bribes cannot commit not to ask for bribes again in the future, a change in the rules themselves through politician intervention is much more difficult to overcome. In other

\footnotetext{
${ }^{4}$ See Drazen (2000), Persson and Tabellini (2000) and Grossman and Helpman (2001) for surveys of the extensive theoretical work on lobbying, while Potters and Sloof (1996) survey the empirical literature. Bardhan (1997), Aidt (2003) and Svensson (2005) survey the work on corruption.
} 
words, through lobbying politicians, a firm is much more assured that in the future there won't be a need for further payments to someone in the public sector. The second key assumption is that a firm's bargaining power vis-à-vis bureaucrats is decreasing in the level of investment that the firm commits to, while this is less of a problem for lobbyists facing politicians. This means that at higher levels of development, lobbying will tend to be the dominant method of influence while bribing will tend to dominate at low levels of development where bribes are relatively inexpensive. It is easy to see that this theoretical framework produces important and testable implications. The first is that lobbying and corruption should be negatively related: a firm that chooses to bribe bureaucrats in order to exert influence should be less likely to be involved in lobbying. Secondly, lobbying should be relatively more important as an instrument of influence for bigger firms or firms in more developed countries while corruption should be more likely for smaller firms or firms in less developed countries.

Harstad and Svensson (2005) do not explicitly discuss the effect of political stability but it is easy to see that in their framework high political instability should make lobbying less effective. This is because in any political system where governments change relatively often, any concession obtained from the current government is fragile and liable to be overturned by different politicians unless they are lobbied again. Thus, the lack of commitment problem attributed to bribing would also become a problem in the context of lobbying. ${ }^{5}$

A second contribution that studies the relationship between corruption and lobbying is that by Damania et al. (2004). The crucial distinction with the Harstad and Svesson (2005) approach is that here corruption and lobbying are viewed as complements, not substitutes. More specifically, the idea is that lobbying is not done in order to change the rules favorably,

\footnotetext{
${ }^{5}$ Hoff et al. (2005) provide a similar rationale. They argue, within the context of transition countries, that political stability is more conducive to corruption because investments in connections with politicians have bigger payoffs if these politicians are likely to remain in power. Clearly, this also applies to lobbying.
} 
thus making bribing unnecessary, but it is done to persuade politicians to underinvest in law enforcement, thus making bribing easier. This means that, contrary to the previous framework, firms that choose to bribe bureaucrats are also more likely to exercise influence through lobbying. With respect to stability, the prediction is again very different. Here, unstable political systems are more likely to generate lobbying. The mechanism is that firms feel more threatened by instability as they worry that future governments will be keener to enforce the law. Since law enforcement requires significant investments, lobbying for underinvestment today will significantly undermine any future government’s law enforcement efforts.

We investigate these alternative theories by focusing on firms' decisions to join trade associations or lobby groups, interpreted as a proxy for their decision to lobby politicians. This allows us to go further in our empirical analysis than Damania et al. (2004) since they don't have a direct measure of lobbying activity. In addition, we can also directly test some other theoretical claims. For instance, Olson (1965) argues that lobby groups are more likely to form when free riders are easier to detect and discourage. Another aspect we investigate is motivated by the Grossman and Helpman's model (1994), which implies that pressure from international competition varies by sectors of activity and, thus, different sectors show different propensities to lobby (for protection). ${ }^{6}$

With specific reference to business lobbies, the first issue implies that lobby groups are more likely to form in more concentrated sectors. By the same reasoning, larger firms would be more willing to join a lobby. On the other hand, smaller firms could have more benefits from joining a lobby because they have fewer means of direct influence on political institutions. In our empirical analysis, we try to determine which of these two opposite effects

\footnotetext{
${ }^{6}$ See Goldberg and Maggi (1999) for empirical evidence. Solanko (2003), referring to a theoretical extension by Baldwin and Robert-Nicoud (2002) of the Grossman and Helpman (1994) framework, argues that small and medium firms and those who are "winners" in sectors where entry is relatively easy should be the least likely to lobby.
} 
is more important. Following Grossman and Helpman (1994), one can also conjecture that sector of activity significantly affects the decision to lobby: different sectors show different propensities to lobby for protection from foreign competition. As this threat is admittedly difficult to measure empirically, we favor the use of sector indicator variables as an important control.

Naturally, there are other intervening factors in a firm's decision to join a lobby group. An issue that has received little attention is the direct impact of political institutions on lobby formation. We conjecture that the number of veto players in the political system has a positive influence on a firm's decision to lobby. In political systems with many veto players such as parliamentary systems, where coalition governments are common, firms are less likely to have direct access to all those players relative to a system where the number of players it needs to influence is small. Therefore, a professional organization such as a lobby that can pool resources and coordinate influence is more likely to be effective.

In principle, the decision to join a trade association may not be entirely due to expectations about the association's or the lobby's actual ability to influence politicians or bureaucrats. For example, since we don't have information about the costs a firm has to pay to join, it is conceivable that if these were low, then firms would join simply to enjoy other benefits, such as networking. ${ }^{7}$ We can get a handle on these issues by analyzing whether firms who do join lobby groups feel more or less capable of influencing different policy makers. This is important because for developed economies, there is a consensus that lobbying is an effective instrument for influencing policy makers. However, as far as less developed countries are concerned, one might conjecture that the effectiveness of lobby groups might still be low vis-à-vis the effectiveness of the more direct kind of influence that

\footnotetext{
${ }^{7}$ See Olson (1965) for a discussion of these secondary benefits that lobby groups bring to their membership.
} 
corruption can provide. Our results below show that this intuition is incorrect and that special interest groups are an important instrument of influence in transition countries. ${ }^{8}$

\section{Data and Methodology}

In this section, we describe the main features of the data set and of the econometric methodology we use to test the hypotheses outlined above. Our main data source is the Business Environment and Enterprise Performance Survey (hereafter, BEEPS). This is a survey of firms that was conducted in 1999 by the European Bank for Reconstruction and Development (EBRD) and The World Bank. It covers a total of 3954 firms in 25 transition countries which were surveyed through face-to-face interviews with firm managers and owners. $^{9}$

The 25 countries, with the number of firms interviewed (in parenthesis), are as follows: Albania (163), Armenia (125), Azerbaijan (137), Belarus (132), Bosnia (127), Bulgaria (130), Croatia (127), Czech Republic (149), Estonia (132 ), Georgia (129), Hungary (147), Kazakhstan (132), Kyrgyzstan (166), Latvia (112), Lithuania (136), Macedonia (136), Moldova (139 ), Poland (246), Serbia and Montenegro (65), Romania (125), Russia (552), Slovakia (138), Slovenia (125), Ukraine (247) and Uzbekistan (126).

In order to ensure representativeness, statistical offices in each country were contacted and the total number of firms by industry and number of employees were obtained. ${ }^{10}$ Information was also collected from the statistical offices on the share of each industrial sector in Gross Domestic Product so that, for each country, the composition of the firms in the sample reflects differences in the relative shares of each sector in GDP as well as their size distribution. This can be seen, for example, in the fact that almost 50\% of the Bulgarian firms

\footnotetext{
${ }^{8}$ Frye (2002) makes a similar point but his study focuses solely on Russia.

${ }^{9}$ The BEEPS data set is available on-line at http://info.worldbank.org/governance/beeps/

${ }^{10}$ The sample is representative of firms operating in the formal sector and thus having a registration number with the central authorities (in other words, it excludes those in the informal sector, and grey or second economy). The samples were drawn for each country independently.
} 
interviewed operate in manufacturing, while about $40 \%$ of those firms interviewed in the

Czech Republic operate in the service sector.

Central to our analysis is the data on lobby membership and corruption from the BEEPS database. On the former, firms were asked whether or not they were a member of a trade association or lobby group at the time of the interview. ${ }^{11}$ A positive answer was coded “1,” while the value of zero was given to a negative answer. On average, about a quarter of the firms in our sample said they were members of a lobby group (see Table 1). The relatively large standard deviation indicates that these figures may vary considerably across countries. Figure 1 plots country averages against the level of per capita GDP (the source for the latter is the Penn World Tables, Version 6.1 and the data refers to the log of per capita GDP at purchasing power parity for the year of the survey, 1999). From Figure 1, Hungary and Slovenia have very high proportions of firms that are members of lobby groups $(77 \%$ and 67\%, respectively), while Azerbaijan and the Kyrgyz Republic are among those with the lowest percentages (6\% and $8 \%$, respectively). ${ }^{12}$ Figure 1 also suggests that there is a positive correlation between lobby membership and per capita GDP, which can be confirmed from Table 2. However, this correlation is not particularly high, at around 0.2.

\footnotetext{
${ }^{11}$ It is also possible that firms lobby directly in addition or as opposed to lobbying indirectly through a trade association or lobby group. Unfortunately, our data does not contain information on this. Note also that, unfortunately, the question as phrased does not separate trade associations from lobby groups when it is not unreasonable to expect that their effects may differ as the latter tend to be more focused (contrast say an environmental lobbying group with a trade association that lobbies for a broad range of issues that are of interest to their membership). Finally, note that "membership" seems to be the standard way of proxying for lobbying in the empirical literature (Potters and Sloof, 1996.)

${ }^{12}$ It should be mentioned that although for some countries membership in trade associations is mandatory, we do not observe $100 \%$ membership in our data. This may be caused, inter alia, by weak enforcement or rapidly changing legislation. For example, in 1999 the Hungarian government changed the Law on Chambers of Economy and Commerce, thus abolishing mandatory membership. For the sake of robustness, we re-estimated all models reported in tables 3 and 4 below without the Hungarian and Slovenian firms and find that our main results were unaffected (these are available from the authors upon request). Admittedly, it is a deficiency of this data set that information on lobbying is restricted to firm membership, and does not include values of membership fees, whether it is voluntary, the matter of political campaign contributions, and frequency of meetings. Given that this is a common deficiency of the empirical literature on lobbying, future research would do well in studying these aspects.
} 
We use two different sources to create two different measures of corruption. The measures differ in that one captures our firms' experience with corruption in each country, while the other reflects aggregate, country-level, views on the extent of corruption. The firmlevel corruption measure is originally from the BEEPS data base. In our analysis, it is a dummy variable that was coded " 1 ” if the firm answered that firms "like yours" typically pay $10 \%$ or more of total revenue per annum in unofficial payments to public officials (and zero, otherwise). ${ }^{13}$ As shown in Table 1, on average $60 \%$ of the firms in our sample believe that this is indeed the case in their particular countries and industries. As shown in Figure 2, there is substantial variation in these answers, with more than $80 \%$ of Serbian firms saying that it is common that more than $10 \%$ of annual revenue is earmarked to bribes and other illegal payments, while "only" $40 \%$ of firms in Albania believe this to be the case. Figure 2 also suggests that there is a (surprisingly) positive correlation between firm-level corruption and per capita GDP, although the value of the pair-wise correlation coefficient value is very low, at about 0.05 (Table 2). ${ }^{14}$

Our second measure of corruption is an aggregate (country-level) measure that has been used in related empirical research (e.g., Damania et al. 2004). It is source is the Nations in Transit report from The Freedom House (2000). ${ }^{15}$ These rankings are based on detailed reports for each country on nine different areas, corruption being one of them. The Freedom House corruption rankings reflect the perception of corruption in the civil service, the business interests of top policy makers, laws on financial disclosure and conflict of interest,

\footnotetext{
${ }^{13}$ The cut-off value of $10 \%$ is admittedly arbitrary. In its defense, we offer that this threshold was chosen for this categorical variable as a rough estimate of expected rates of return to investment in the "average sector in the average country": if firms have to pay such a high percentage of revenues in unofficial payments to public officials it may be difficult for them to break-even. With this concern in mind, we have re-coded this variable by lowering as well as by increasing this threshold and we have also tried using dummy variables for each category (of percentage of revenue) but none of these affect qualitatively the results reported in the next section.

${ }^{14}$ It is, however, statistically significant at the 5 percent level.

${ }^{15}$ Notice that this variable differs from the often used Freedom House ratings for Political Rights and Civil Liberties in that this corruption measure is continuous, that is, it is not a categorical variable. The data is available on-line at http://www.freedomhouse.org/research/nattransit.htm
} 
and the efficacy of anticorruption initiatives. The Freedom House specialists, on the basis of these reports (notice that the individual country reports are also available on-line), rate each country on a one-to-seven scale, with one representing the lowest and seven the highest level of corruption. The average for the countries in our sample, concurring with our other measure of corruption, is rather high at about a score of 5 in year 1999. As it can be seen in Figure 3, Serbia and Russia were the most corrupt countries in our sample in 1999 with both scoring 6.5, while Slovenia is the country ranked least corrupt in 1999, having a score of 2 . It is also clear from the Figure that there is a negative relationship between aggregate corruption and per capita GDP with a correlation coefficient of around -.7. Notice that this is one of the highest correlations in Table 2 (the other is the one between this aggregate measure of corruption and our aggregate measure of political instability, discussed below) suggesting that country-level data may mask important features of corruption and have led analysts to believe that corruption would be the preferred method of influence in poorer countries.

Our measures of influence reflect firms’ perceptions in four different spheres: over the executive branch of government, legislative, ministries and regulatory agencies. The source is again the 1999 BEEPS data base. The pair-wise correlation coefficients among these four variables are very high (see Table 2). This is an interesting finding in itself. It suggests that if was true firms favor direct methods of influence, we would observe low coefficients because it would be prohibitively expensive (especially for the small firms that are a majority in our sample) to exert influence in all these four areas simultaneously. We obtain the opposite result, thus suggesting that lobbying may be playing an important role (in what follows we investigate how important this role actually is, in absolute terms and vis-à-vis corruption).

We must emphasize that the availability of data on perceived influence on these four spheres is very important for the credibility of our results. A critic may well argue that the use of such measure of influence bias our results against corruption because while lobbying is important with respect to policy makers, corruption is important vis-à-vis "policy-enforcers," 
that is, agencies that implement and enforce policies. In this paper we can differentiate their effects vis-à-vis the executive, legislative, ministries and regulatory agencies. We think it is reasonable to think of the first two as "policy-makers" and of the last two as "policyenforcers.” As we will show below, for none of these our spheres, our firms report corruption as more effective than lobbying.

For all four of these spheres of influence, our measure is a binary variable coded 1 if the firm answered “influential”, "frequently influential” or "very influential” to the following question: "When a new law, rule, regulation, or decree is being discussed that could have a substantial impact on your business, how much influence does your firm typically have at the national level of government to try to influence the content of that law, rule, regulation or decree?” It is coded zero if the firm answers “never influential” or “seldom influential.”16

Table 1 shows that the averages of all our four measures of influence are not very high and are similar in size (between $25 \%$ and $30 \%$ of the firms perceive themselves as influential). Again, this conceals large variations across countries. For example, in the case of influence over the executive, while around $60 \%$ of the firms in Croatia see themselves as influential, only $8 \%$ of them would say the same in Belarus. In the case of influence over the legislative, although around $40 \%$ of the firms in Slovakia see themselves as influential, only $5 \%$ of them would say so in Azerbaijan. Finally, while in Latvia almost $60 \%$ of the firms see themselves as influential vis-à-vis the regulatory agencies, that same figure for firms in Hungary does not reach $15 \%$. Unexpectedly, firms that see themselves as influential, tend to do so for all four areas at the same time.

From the BEEPS data set, we get various auxiliary variables to capture different characteristics of the firms. These are the year in which the firm started production, the size of

${ }^{16}$ A critic may charge that transforming such a rich categorical variable into a dummy variable in this fashion may entail a costly loss of information. We justify this choice by arguing that attention to the possibility of endogeneity bias are central in our analysis and such a loss of information is needed to jointly estimate our influence, lobbying and corruption equations in what follows. With this concern in mind, however, we have also re-estimated our single "influence equations" by ordered probit but we find that this does not affect qualitatively the results reported in the next section. 
the firm in terms of full-time employees, ${ }^{17}$ whether or not any state agency has a disclosed financial stake in the firm, whether or not any foreign-owned firm (or government) has a disclosed financial stake in the firm, and whether or not the firm headquarters are located in the capital city. An additional hypothesis we test is regarding the effect of a parliamentary system on the probability of a firm being a lobby member. The Database on Political Institutions (DPI) provides data on this issue. ${ }^{18}$ Basic statistics, pair-wise correlations, description and sources of these auxiliary variables are provided in Tables 1 and 2.

As discussed in the previous section, in addition to features of the political system, we are also interested in understanding the role of political instability on the probability of an individual firm being a member of a lobby group. In order to capture political instability, we use a similar approach to the one for corruption in that we again construct both firm-based and country-level measures. The former is from the BEEPS data base and is coded 1 if a firm answered "predictable” to "how predictable are changes in rules, laws or regulations, which materially affect your business?” and 0 otherwise. As it can be seen from Table1, approximately $28 \%$ of the firms in our sample indicated that such changes are predictable. Our other measure for political stability (now at the country level) is the one used by Damania et al. (2004) and its source is Kaufmann et al. (1999). It captures the likelihood that the government will be destabilized or overthrown. It takes values from -2.5 to 2.5 , where a higher value represents greater political stability. The average for our sample is approximately zero, however these values range from 1.3 for Hungary to about -1.4 for Serbia and Montenegro.

We now turn to the econometric methodology. There are two main questions of interest: (a) what are the factors that determine the likelihood of a firm being a member of a lobby

\footnotetext{
${ }^{17}$ Samples reflect the sectoral and size distribution of firms in each country. Therefore, most firms are small and medium enterprises, with less than 50 full-time employees in 1999.

18 See Beck et al. (2001) for more details. The DPI data is available on-line at http://www.worldbank.org/research/bios/pkeefer/DPI2000_distributed.zip
} 
group? And (b) what is the relative role of corruption and lobby membership in explaining the probability of a firm seeing itself as influential vis-à-vis government laws, regulations and policies? As noted above, the dependent variable in both cases is a dichotomous variable. In question (a), it takes the value of 1 if the firm is a lobby member and of zero if not. In question (b) it takes the value of 1 if the firm perceives itself as influential, zero otherwise.

An appropriate econometric methodology in this case is maximum likelihood probit estimation. In what follows, we first estimate the probit equation:

$$
P\left(\text { lobby }_{i c}=1\right)=\Phi\left(\beta_{0} F S_{i c}+\beta_{1} \text { Age }_{i c}+\beta_{2} \text { Ownerpriv }_{i c}+\beta_{3} \text { Ownerfor }_{i c}+\beta_{4} G D P_{c}+\pi V_{i c}\right)
$$

where lobbyic is a binary variable indicating whether firm $i$ in country $c$ is a member of a lobby group; FSic is firm size (measured in number of full-time employees); Ageic is the year the firm started to operate; Ownerprivic is whether the firm has private owners; Ownerforic is whether the firm has foreign owners; $G D P_{c}$ is real per capita GDP in the country in which the firm is located; $V_{i c}$ is a vector of auxiliary control variables (including measures of corruption and of political instability); and $\Phi$ is the cumulative standard normal distribution function.

As noted, although most of our auxiliary variables can be treated as exogenous in our lobby equation, the introduction of (any of our two measures of) corruption raises concerns about the possibility of endogeneity bias. We use the Rivers and Vuong (1988) specification test to assess this potential problem. The test is based on the following system of equations:

$$
\begin{aligned}
& Y_{1}=F\left(x_{1}, \theta\right)+v \\
& Y_{2}=H\left(Y_{1}, x_{2}, \theta\right)+u
\end{aligned}
$$

where $\mathrm{F}$ and $\mathrm{H}$ denotes the particular functional form for the probit. The test is conducted by including the residual from the first-stage equation, that is, the regression on $\mathrm{Y}_{1}$, in the model for $Y_{2}$ (the second equation). Therefore, we estimate $Y_{2}=H\left(Y_{1}, x_{1}, \theta, v\right)+$ e and specify the null hypothesis as $\alpha=0$, where $\alpha$ is the coefficient on $\mathrm{v}$. Accordingly, we could not reject the hypothesis of exogeneity for a number suspected variables in this model, principally corruption (a full discussion of these results is provided in section 4 below). This means that 
a single-equation standard probit is the appropriate estimator when looking at the determinants of lobby membership in our sample. However, we did not obtain similar success with this test for our second model (which examines the joint roles of lobbying and corruption on firms’ perceived influence).

The second model we estimate is the following probit equation:

$$
P\left(\text { inlfuence }_{i c}=1\right)=\Phi\left(\delta_{0} \text { lobby }_{i c}+\delta_{1} \text { Corrupt }_{i c}+\eta W_{i c}\right)
$$

where influence ic is a binary variable indicating whether firm $i$ (in country $c$ ) perceives itself as influential vis-à-vis four different spheres (as noted above, executive, legislative, ministry and regulatory agency); lobbyic is the binary variable defined above; Corruptic is our measure of corruption (which can be country-level or alternatively firm-based); $W_{\text {ic }}$ is a vector of auxiliary control variables (including per capita GDP, firm ownership, headquarters location and measures of political instability); and $\Phi$ is the cumulative standard normal distribution function.

In this second model we are concerned about the potential endogeneity of lobby membership as well as of corruption. The issue concerns the possibility that (at least) one of the explanatory variables in the influence equation (i.e., corruption or lobbying) is endogenous: firms may be more likely to join lobby groups if and when such groups are perceived to be influential (or if the government is perceived to be sensitive or amenable to influence). Wald exogeneity tests were carried out and although they fail to reject the assumption of exogeneity of corruption, they do reject the assumption of exogeneity for lobbying membership. It is therefore important to address the possibility that the probit estimates might be inconsistent. In order to take this issue into account, we apply the Newey's (1987) efficient two-step minimum chi-squared estimator. ${ }^{19}$ In a nutshell, in what follows we estimate the influence equation (equation 3) treating corruption as an exogenous variable and

\footnotetext{
${ }^{19}$ This econometric approach has been used in many other areas of empirical research, as for instance in Ribar (1994) and more recently in McKenzie and Rapoport (2004).
} 
lobbying as an endogenous variable. We do the latter by using equation (1) as the first-stage regression.

\section{Results}

In this section, we present the econometric results for the hypotheses discussed in section 2 using the data and methodology from section 3. We begin by discussing Table 3 which shows our probit estimates for the determinants of a firm's decision to join a lobby group. ${ }^{20}$ There are a number of important results. In terms of the firm characteristics, our results show that the number of full-time workers (firm size) has a significant and positive impact on the decision to join a lobby group. The marginal effect is considerable. The firm being of a large size increase the probability of being a lobby member by between 15\% (in column 1) and 17\% (in the remaining columns of Table 3). As discussed in section 2, there are contrasting theoretical arguments for the relationship between firm size and the decision to join a lobby. Our result favors the Olsonian argument that lobby groups with larger (and thus fewer) members are more effective, but it is also compatible with the view expounded in Solanko (2003) and Hellman and Kauffman (2002) that in transition economies lobbying is effective mostly for large firms. ${ }^{21}$

Our analysis also shows that if the firm is foreign-owned it is more likely to be a member of a lobby group. On average, for all our specifications, if a firm has foreign shareholders, the probability of joining a lobby group increases by around $8 \%$. This is a statistically large and economically meaningful effect. This is intuitive since foreign owners are likely to be from more developed economies where corruption is much less common and

\footnotetext{
${ }^{20}$ Note that results from the linear probability model as well as those imposing clustered (country) standard errors are qualitatively similar to those reported below.

${ }^{21}$ Solanko (2003) also predicts that lobbying be less likely amongst high performing firms in sectors where entry is relatively simple. Our data does not allow us to test this hypothesis since we don't have measures of barriers to entry.
} 
lobbying may be the preferred instrument of influence so that the management of these firms is more likely to pursue the same methods. ${ }^{22}$

The results obtained with respect to the level of economic development are compatible with those in Bischoff (2003) who shows that, among OECD countries, this is a significant factor in the decision to join a lobby. The elasticity of lobby membership with respect to per capita GDP is large (9\% to $13 \%$ ) in all specifications in which the variable is statistically significant. The result also confirms the Harstad and Svensson (2005) prediction that lobbying is positively associated with the level of economic development. This is important because it also indicates that the switch from corruption to lobbying as a major method of influence seems to be already occurring within less developed countries, not after full development has been achieved, as one might conjecture. ${ }^{23}$ When we introduce our country-level measure of corruption (from Freedom House) this result disappears due to the high (inverse) correlation between the two variables. Yet the result remains when we use the firm-level (from BEEPS) measure of corruption. We also find that whether a firm has private sector owners or not does not significantly affect the probability of joining a lobby. This might sound surprising at first but is compatible with Frye (2002)'s evidence on Russia, which suggests that the distinction between private and public ownership does not matter so much for lobbying national policy makers. ${ }^{24}$ The results also show that firms located in the capital city are more likely to be members of lobby groups. ${ }^{25}$

\footnotetext{
${ }^{22}$ Unfortunately, the questions on the percentage of ownership and on the nationality of the foreign owner were almost never answered in this survey.

${ }^{23}$ Despite the high pair-wise correlations involving our country-level measure of corruption, multicollinearity does not seem to be a severe problem in this case. The largest Variance Inflation Factor (VIF) is around 5, which is well below the conventional critical value of 10 .

${ }^{24}$ Frye (2002) presents evidence that ownership structure matters for lobbying policy makers at regional level. Our data does not allow us to make the distinction between national and local policy makers.

${ }^{25}$ There is previous empirical evidence (e.g. Sobel and Garrett 2002) that firms located in centers where policy decisions are made tend to lobby more. One issue this raises is whether firms locate in capital cities for lobbying purposes. Further, there is also concern about the possibility of corruption being endogenous to the decision of joining a lobbying group. Our exogeneity tests indicate we can not reject the hypotheses that each of these two variables is exogenous. The p-value of this test is .806
} 
Our most important findings concern the effects of corruption on the decision to join a lobby group. We find that corruption has a negative and significant impact, while political stability has a positive and significant impact on the decision to join a lobby. As discussed in the previous section, various exogeneity tests were conducted and we could not reject the hypotheses that corruption (whichever way we measured it) is exogenous for all specifications (Table 3). The result is that the effect of corruption on lobby membership is direct, negative and economically meaningful. A country experiencing change from being non-corrupt to being corrupt yields a decrease in the probability of being a lobby member of about 3\% and a similarly sized effect obtains for our firm-level measure of corruption. Indeed, it is remarkable that this marginal effect is very much same in the three specifications in Table 3 for which the coefficient on corruption is statistically significant. ${ }^{26}$

This negative and significant impact of corruption on lobbying is compatible with the Harstad and Svensson (2005) framework because they suggest that corruption and lobbying are substitutes and that political stability does encourage further lobbying. How does this reconcile with the Damania et al. (2003) results who suggest otherwise? First of all, we note that while their theoretical model finds a positive relationship between political instability and judicial inefficiency (and thus, corruption) through the lobbying activity of firms that ask governments to underinvest in law enforcement, their empirical data can only capture the direct link between political instability and judicial inefficiency but not how these relate to lobbying. It is therefore quite conceivable that political instability leads to judicial inefficiency through other mechanisms or even directly. For example, countries where governments change frequently may end up having underinvestment in law enforcement

for our firm-level corruption measure, .9596 for our country-level corruption measure, and .3475 for the firm's headquarter location.

${ }^{26}$ These results are robust to the presence of sector fixed-effects. Notice, however, that the latter vary quite a bit across specifications. With this caveat in mind, manufacturing and financial services tend to carry positive and statistically significant coefficients. Because these involve mostly tradable sectors, these results can be seen as supporting the Grossman and Helpman (1994) lobbying for protection argument. 
simply because different governments do make investments in law enforcement but these are incompatible with each other. In other words, our results lead us to believe that Damania et al. (2003) discovers a link between political instability and corruption but suggests that lobbying by firms may not be the relevant mechanism. It is also very important to note that contrary to Damania et al. (2003) we have access to disaggregated measures of (perceived) stability and corruption, not just country-level measures. Indeed, our results hold for both firm level and country level measures of corruption and stability, even though table 2 shows them to be highly uncorrelated with each other. This is not entirely surprising: Svensson (2003) has shown how country level measures of corruption can be quite misleading in measuring the extent to which a given firm perceives the level of corruption it deals with.

With respect to our pair of measures of political stability, we emphasize that while at the country level we have a measure of government turnover, at the firm level, we have a measure of how predictable firms perceive policy changes to be. ${ }^{27}$ These are obviously different things, although both capture important notions of stability. The magnitude of these effects is considerable: focusing on the firm level data, a firm that perceives that over $10 \%$ of revenue per year has to pay corrupt officials is on average 3\% less likely to join a lobby group while a firm that perceives policy to be stable is on average $3.5 \%$ more likely to join a lobby group. The magnitude of these effects for country level variables is similar.

Another important result is that the characteristics of national political institutions have a positive impact on the likelihood of being a lobby member. Table 3 shows that in countries with a parliamentary system, firms are more likely to join lobby groups. We conjecture that this is because the number of veto players tends to be greater in parliamentary than presidential systems. ${ }^{28}$ This effect is strong: firms in parliamentary systems are on

\footnotetext{
${ }^{27}$ It is beyond the scope of this paper to examine a broader array of political instability issues. Future research should study the role of events such as coups, civil wars, riots and government purges.

${ }^{28}$ See Persson and Tabellini (2003) for a discussion of the relationship between government structure and veto players.
} 
average $15 \%$ more likely to join a lobby group. The magnitude of this effect suggests that future research would do well to further investigate this connection.

In sum, we find that both firm characteristics and institutional features of the country in which these are located contribute to explain lobby membership. On the former, we identify that firm age, size and ownership significantly increase the likelihood of a firm being a lobby member in a transition country, while the same effect is evident if the country in which the firm is located has a parliamentary system, and is politically stable. In all cases (with the exception of the regression where we account for aggregate corruption and political instability), we can also add that the likelihood of being a lobby member decreases with the level of corruption (which suggests that these are substitutes).

Let us now turn to the determinants of aggregate influence. Tables 4a-4d reports these results which are ascertained on four different public sector institutions: the chief executive, legislature, ministries and regulatory agencies. We present results both for a standard probit model and for the instrumental variable probit model discussed in the previous section. The latter allows us to address the issue of potential joint determination that seems to affect the lobby membership and influence variables. Although we could never reject the hypothesis that corruption is exogenous, ${ }^{29}$ the hypothesis that lobbying is exogenous was rejected for all cases. It is thus wise to instrument for lobbying and to do that, we use those in Table 3 as first-stage regressions in this case. In what follows, we report the coefficients from both the single-equation and the simultaneous-equation probit so that the comparison between the relative effects of corruption and lobbying on political influence can be examined in full.

Focusing first on the results for lobbying, we find a positive, statistically significant and economic meaningful relation between lobby membership and perceived influence for all four targets. For instance, an increase in $1 \%$ on the probability of being a lobby member

\footnotetext{
${ }^{29}$ For instance, the p-values from a Wald test of exogeneity for our country-level corruption measure in each of the four spheres (in Table 4) is as follows: .959, .606, .997, .616. The same p-values for lobby membership are about .0001 in all cases.
} 
increases perceived influence on the executive by 16\% (using the specification in column 1 of Table 4a), while the effect of corruption is not statistically significant. ${ }^{30}$ This result seems to confirm that firms who join lobby groups do so, at least in part, in order to gain influence. Interestingly however, the effect seems to be weaker for influence with regulatory agencies (table 4d), further confirming the suspicion that lobbying tends to focus on policy makers, not on those who execute policies. One may conjecture that the preferred mean of influence on those who execute policies is corruption. Yet, our results do not support this alternative view. Indeed, our analysis does not point to a significant impact on aggregate influence of the level of corruption in the country (the result holds irrespective of the estimator or the measure of corruption we use). ${ }^{31}$ One of our main results indeed is that lobbying seems a much more effective mean of exerting influence than corruption. Tables 4a to 4d report 16 different coefficients of corruption on influence and not a single one of them is statistically significant. This contrasts sharply with our results for lobbying in which all but one of the coefficients is statistically significant. Further, in terms of their relative magnitude, the marginal effects from lobbying are on average 10 -fold those from corruption, suggesting that this relative effect is considerable. $^{32}$ It is important to keep in mind that these results obtain in a set of countries for which it is widely held that corruption levels are very high.

With respect to the other variables of interest, we find that private ownership has a negative impact on perceived influence, as publicly owned firms are clearly closer to state institutions. Interestingly, foreign ownership is also positively correlated with perceived influence although the evidence is somewhat stronger for the executive than for the other

\footnotetext{
${ }^{30}$ As before, because of the high correlations observed with our country-level corruption measure, we computed the variance inflation factors. The maximum values are again around 5 , which is well below the conventional critical value of 10 .

${ }^{31}$ Despite the high correlations involving our country-level measure of corruption, multicollinearity does not seem to be a severe problem here. The largest Variance Inflation Factor (VIF) for the singleequation probits is 4.32 (for the country-level measure of corruption in the regulatory agency equation), which is well below the conventional critical value of 10 .

${ }^{32}$ Given the frailty of the results on corruption, it is not surprising that interaction terms between our corruption measures and lobbying membership are never statistically significant.
} 
branches. This may suggest that in order to attract foreign investment, governments are particularly attentive to requests from foreign investors.

The one factor other than lobbying that seems to consistently explain influence well is the firm-level measure of political stability, which is always significantly associated with influence (while our country-level measure is not). This may suggest that the effect of this kind of predictability is indirect and works mostly through the lobbying channel. Interestingly, we do not find significant evidence of a link between levels of development (as measured by per capita GDP) and perceived aggregate influence. The link only seems to be negative and significant for the case of the executive, perhaps suggesting that high-level influence is not as linked to development levels as one would suspect and that much of the effect happens through lobbying.

\section{Conclusions}

This paper studied the determinants of lobby membership among firms, and the relative roles of lobbying and corruption in producing political influence. Using data for about 4000 firms in 25 transition economies, our results show that, as supported by previous studies, the decision to join a lobby group is positively correlated with firm size and economic development. We also show, however, that the percentage of foreign investment in the firm and the number of veto players in the political system have a positive influence on this decision. More importantly, we provide evidence compatible with our conjecture that lobbying is a substitute for a firm's direct means of influence with policy makers (such as corruption). Finally, our results indicate that firms who join a lobby see themselves as more able to influence decision makers thus showing that (a) a lobby group’s ability to exert influence is an important factor in a firm's decision to join and (b) that while lobbying may be increasingly effective as a country develops (that is, becomes richer), it already matters a lot even in less developed (in our case, transition) countries. Our results indeed suggest that even 
among poorer or less developed countries, firms believe that lobbying is a more effective mean of exerting political influence than corruption.

As our analysis indicates, there clearly is significant scope for further research. In particular, our data on lobbying and corruption does not address completely how the different kinds of corruption and lobbying activities interact with each other. For example, we still don't know exactly what lobbying actually accomplishes: our results are compatible with the theory that lobbying does not try to undermine law enforcement but rather tries to change policy directly. But this is still indirect evidence. Fortunately, some recent work has begun to ask some of these questions. In a very recent paper by Recanatini et al. (2005), for example, there is emphasis on the supply side of corruption that is mostly absent from our analysis. This is a step forward because it tells us what are the disaggregate characteristics that make specific public institutions inherently more vulnerable to corruption and why. In particular their results suggest that public agencies where monitoring is frequent, where procedures are detailed and clear and where careers within the agency are based on merit are less vulnerable to corruption. An equivalent analysis for the factors that affect the ability to lobby specific public sector institutions would go a long way in clarifying lobbying's role in different societies. 


\section{References}

Aidt, T. (2003) "Economic analysis of corruption: A survey”, Economic Journal 113 (491), F632-F652.

Austen-Smith, D. and J. R. Wright, (1994) "Counteractive lobbying," American Journal of Political Science vol. 38, n. 1, pp. 25-44

Bardhan, P. (1997) “Corruption and development: A review of issues”, Journal of Economic Literature, vol. 35, pp. 1320-1346.

Baldwin, R.E. and F. Robert-Nicoud (2002) "Entry and asymmetric lobbying: Why governments pick losers” NBER Working Paper 8756.

Beck, T., G. Clarke, A. Groff, P. Keefer, and P. Walsh (2001) "New tools in comparative political economy: The database of political institutions" World Bank Economic Review 15: 165-176.

Bennedsen, M. and S. Feldmann (2005), "Informational Lobbying and Political Contributions”, Forthcoming, Journal of Public Economics.

Bischoff, I. (2003), "Determinants of the Increase in the Number of Interests Groups in Western Democracies: Theoretical Considerations and Evidence from 21 OECD Countries.” Public Choice vol. 114, pp. 197-218.

Coate, S. and S. Morris (1999), “Policy Persistence” American Economic Review 89: 1327-1336.

Dahm, M. and Porteiro, N. (2004), "The Carrot and the Stick: Which is the Lobby's Optimal Choice?” Working Paper, Kellogg School of Management.

Damania, R., Fredricksson, P.G. and M. Mani (2004), “The Persistence of Corruption and Regulatory Compliance Failures: Theory and Evidence” Public Choice vol. 121, pp. 363-390.

Drazen, A. (2000), Political Economy in Macroeconomics, Princeton University Press.

Frye, T. (2002) "Capture or Exchange: Business Lobbying in Russia." Europe-Asia Studies vol. 54, pp. 1017-1036.

Goldberg, P. and G. Maggi (1999), "Protection for Sale: An empirical investigation,” American Economic Review vol. 89, pp. 1135-1155.

Grossman, G. and E. Helpman (1994), “Protection for Sale.” American Economic Review vol. 84, pp. 833-850.

Grossman, G. and E. Helpman (1999), "Competing for Endorsements". American Economic Review vol. 89, pp. 501-524.

Grossman, G. and E. Helpman (2001), Special Interest Politics, MIT Press.

Harstad, B. and J. Svensson (2005) "Bribe or Lobby? (It's a Matter of Development)". Mimeo. Northwestern University. 
Hellman, J. and D. Kauffman (2002) “The Inequality of Influence”. Mimeo, World Bank.

Hoff, K., Horowitz, S. and B. Milanovic (2005) "Political Alternation as a Restraint on Investing in Influence: Evidence from Transitions Countries,” World Bank, mimeo.

Kaufmann, D., Kraay, A. and Zoido-Lobaton, P. (1999), “Aggregating governance indicators,” Policy Research Working Paper \# 2195, The World Bank.

McKenzie, D. and H. Rapoport, (2004) "Network effects and the dynamics of migration and inequality: theory and evidence from Mexico”. Mimeo, Stanford University.

Mitra, D., Thomakos, D. and M. Ulubasoglu (2002), “'Protection for Sale' in a Developing Country: Democracy vs. Dictatorship” Review of Economics and Statistics 84: 497-508.

Newey, W. (1987), "Efficient Estimation of Limited Dependent Variable Models with Endogenous Explanatory Variables” Journal of Econometrics vol. 36, pp. 231-250.

Olson, M. (1965), The Logic of Collective Action: Public Goods and the Theory of Groups, Harvard University Press.

Persson, T. and G. Tabellini (2000), Political Economics, MIT Press.

Persson, T. and G. Tabellini (2003), The Economic Effects of Constitutions, MIT Press.

Potters, J. and R. Sloof (1996) "Interest Groups: A Survey of Empirical Models That Try To Assess Their Influence”, European Journal of Political Economy vol. 12, pp. 403-442.

Recanatini, F., Prati, A. and G. Tabellini (2005) "Why are some Public Agencies Less Corrupt than Others? Lessons for Institutional Reform from Survey Data”. Mimeo.

Ribar, D. (1994) “Teenage Fertility and High School Completion,” Review of Economics and Statistics vol. 76, n.3, pp. 413-424.

Rivers, Douglas, and Quang Vuong (1988), "Limited Information Estimators and Exogeneity Tests for Simultaneous Probit Models,” Journal of Econometrics vol. 39, pp. 347-366.

Sobel, R. and T. Garrett (2002) "On the Measurement of Rent Seeking and Its Social Opportunity Cost,” Public Choice vol. 112, pp. 115-136.

Solanko, L. (2003) "Why favor large incumbents? A note on lobbying in transition”, BOFIT Online, N.6.

Svensson, J. (2003) "Who Must Pay Bribes and How Much? Evidence from a Cross Section of Firms”, Quarterly Journal of Economics vol. 118, n. 1, pp. 207-30.

Svensson, J. (2005) "Eight Questions about Corruption”, Journal of Economic Perspectives vol. 19, n. 3, pp. 19-42.

Yalcin, E. and R. Damania (2005) “Corruption and Political Competition”. Mimeo. 
Table 1

Basic Statistics, Variable Definitions and Data Sources

\begin{tabular}{|c|c|c|c|c|}
\hline Variable & Mean & Std.Dev. & $N$ & Definition and Source \\
\hline Lobby membership & .2403 & .427 & 3953 & $\begin{array}{l}\text { Dummy variable: } 1 \text { if firm is a member of a } \\
\text { trade association or lobby group, } 0 \\
\text { otherwise. Source: BEEPS } 1999\end{array}$ \\
\hline $\begin{array}{l}\text { Corruption firm } \\
\text { level }\end{array}$ & .605 & .489 & 3954 & $\begin{array}{l}\text { Dummy variable: } 1 \text { if answers that "firms } \\
\text { like yours" typically pay } 10 \% \text { or more of } \\
\text { total revenue per annum in unofficial } \\
\text { payments to public officials, } 0 \text { if less than } \\
10 \% \text {. Source: BEEPS } 1999\end{array}$ \\
\hline $\begin{array}{l}\text { Corruption } \\
\text { aggregate }\end{array}$ & 4.886 & 1.408 & 3954 & $\begin{array}{l}\text { Country-level corruption indexes for } 1999 \text {, } \\
\text { varies from } 1 \text { to } 7 \text { with larger numbers } \\
\text { indicating more corruption. Source: Freedom } \\
\text { House (2000) }\end{array}$ \\
\hline Log GDP & 8.695 & .488 & 3954 & $\begin{array}{l}\text { Log of per capita Gross domestic product } \\
\text { (PPP) in 1999. Source PWT } 6.1\end{array}$ \\
\hline $\begin{array}{l}\text { Influence on } \\
\text { Executive }\end{array}$ & .284 & .451 & 2920 & $\begin{array}{l}\text { Dummy variable coded } 1 \text { if firm answered } \\
\text { "influential”, “frequently influential” or } \\
\text { "very influential” to perceived influence on } \\
\text { executive }\end{array}$ \\
\hline $\begin{array}{l}\text { Influence on } \\
\text { Legislative }\end{array}$ & .276 & .447 & 2935 & $\begin{array}{l}\text { Same as above to its perceived influence on } \\
\text { legislative }\end{array}$ \\
\hline $\begin{array}{l}\text { Influence on } \\
\text { Ministry }\end{array}$ & .285 & .452 & 2953 & $\begin{array}{l}\text { Same as above to its perceived influence on } \\
\text { ministries }\end{array}$ \\
\hline $\begin{array}{l}\text { Influence on } \\
\text { Regulatory Agency }\end{array}$ & .295 & .456 & 2818 & $\begin{array}{l}\text { Same as above to its perceived influence on } \\
\text { regulatory agencies }\end{array}$ \\
\hline $\begin{array}{l}\text { Year of firm } \\
\text { foundation }\end{array}$ & 1987.3 & 18.77 & 3859 & $\begin{array}{l}\text { Year in which firm started production. } \\
\text { Source: BEEPS } 1999\end{array}$ \\
\hline Private ownership & .841 & .365 & 3954 & $\begin{array}{l}\text { Dummy variable: } 1 \text { if no state agency has a } \\
\text { financial stake in respondent firm, } 0 \\
\text { otherwise. Source: BEEPS } 1999\end{array}$ \\
\hline Foreign ownership & .127 & .333 & 3947 & $\begin{array}{l}\text { Dummy variable: } 1 \text { if any foreign firm has a } \\
\text { financial stake in respondent firm, } 0 \\
\text { otherwise. Source: BEEPS } 1999\end{array}$ \\
\hline $\begin{array}{l}\text { Headquarters in } \\
\text { capital }\end{array}$ & .309 & .462 & 3954 & $\begin{array}{l}\text { Dummy variable: } 1 \text { if firm headquarters are } \\
\text { located in capital city, } 0 \text { otherwise. Source: } \\
\text { BEEPS } 1999\end{array}$ \\
\hline $\begin{array}{l}\text { Parliamentary } \\
\text { system }\end{array}$ & .266 & .441 & 3827 & $\begin{array}{l}\text { Dummy variable: } 1 \text { if parliamentary system } \\
\text { in 1999, } 0 \text { otherwise. Source: Beck at al. } \\
\text { (2001) }\end{array}$ \\
\hline Medium size firm & .285 & .451 & 3952 & $\begin{array}{l}\text { Dummy variable: } 1 \text { if firm has between } 50 \\
\text { and } 199 \text { full time employees, } 0 \text { otherwise. } \\
\text { Source: BEEPS } 1999\end{array}$ \\
\hline Large size firm & .223 & .416 & 3952 & $\begin{array}{l}\text { Dummy variable: } 1 \text { if firm has between } 200 \\
\text { and above full time employees, } 0 \text { otherwise. } \\
\text { Source: BEEPS } 1999\end{array}$ \\
\hline
\end{tabular}




\begin{tabular}{|l|l|l|l|l|}
\hline $\begin{array}{l}\text { Political stability } \\
\text { country-level }\end{array}$ & -.0197 & .678 & 3954 & $\begin{array}{l}\text { Measures perceptions of the likelihood that } \\
\text { the government in power will be destabilized } \\
\text { or overthrown. It takes values from -2.5 to } \\
\text { 2.5, where a higher value represents greater } \\
\text { political stability. Source: Kaufmann et al. } \\
\text { (1999). }\end{array}$ \\
\hline $\begin{array}{l}\text { Political stability } \\
\text { firm-level }\end{array}$ & .2795 & .448 & 3953 & $\begin{array}{l}\text { Dummy variable: } 1 \text { if firm answer "how } \\
\text { predictable are changes in rules, laws or } \\
\text { regulations, which materially affect your } \\
\text { business?" as unpredictable, 0 otherwise. } \\
\text { Source: BEEPS 1999 }\end{array}$ \\
\hline
\end{tabular}


Table 2

Pair-wise Correlation Coefficients

\begin{tabular}{|c|c|c|c|c|c|c|c|c|c|}
\hline & Lobby & Corrupt & Corrupt & Log & Year 1 & Private & \multicolumn{3}{|c|}{ Foreign } \\
\hline & Member & Agg & Firm & GDP & & & & & \\
\hline Corruption Agg & -0.229 & & & & & & & & \\
\hline Corruption Firm & -0.002 & -0.048 & & & & & & & \\
\hline Log pc GDP & 0.182 & -0.719 & 0.056 & & & & & & \\
\hline Year found & -0.125 & 0.079 & -0.086 & -0.096 & & & & & \\
\hline Private & -0.067 & 0.007 & -0.099 & 0.049 & 0.401 & & & & \\
\hline Foreign & 0.117 & -0.093 & 0.002 & 0.062 & 0.029 & 0.088 & & & \\
\hline Capital city & 0.052 & 0.016 & -0.032 & -0.125 & 0.001 & -0.015 & 0.183 & & \\
\hline Parliamentary & 0.207 & -0.503 & -0.009 & 0.405 & 0.016 & -0.054 & 0.081 & & \\
\hline PolStab Aggr & 0.222 & -0.841 & 0.029 & 0.656 & -0.078 & 0.003 & 0.099 & & \\
\hline PolStab Firm & 0.058 & -0.054 & 0.015 & -0.035 & -0.085 & -0.105 & 0.003 & & \\
\hline Medium size firm & 0.037 & 0.055 & 0.011 & -0.011 & -0.077 & -0.208 & -0.017 & & \\
\hline Large size firm & 0.139 & -0.017 & 0.079 & 0.057 & -0.284 & -0.231 & 0.081 & & \\
\hline Influence Exec & 0.182 & -0.026 & -0.008 & -0.006 & -0.138 & -0.168 & $8 \quad 0.071$ & & \\
\hline Influence Leg & 0.211 & -0.075 & 0.009 & 0.063 & -0.165 & -0.188 & 30.062 & & \\
\hline Influence Min & 0.222 & -0.101 & 0.004 & 0.071 & -0.189 & -0.188 & $\begin{array}{ll}8 & 0.077\end{array}$ & & \\
\hline Influence Reg Ag & 0.171 & -0.034 & -0.010 & 0.022 & -0.176 & -0.183 & $\begin{array}{ll}3 & 0.061\end{array}$ & & \\
\hline & $\begin{array}{c}\text { Capital } \\
\text { City }\end{array}$ & Parlam & $\begin{array}{l}\text { PolStab } \\
\text { Aggr }\end{array}$ & $\begin{array}{l}\text { PolStab } \\
\text { Firm }\end{array}$ & $\begin{array}{l}\text { Medium } \\
\text { Size }\end{array}$ & $\begin{array}{l}\text { Large } \\
\text { Size }\end{array}$ & $\begin{array}{l}\text { Infl } \\
\text { Exec }\end{array}$ & $\begin{array}{l}\text { Infl } \\
\text { Leg }\end{array}$ & $\begin{array}{l}\text { Infl } \\
\text { Min }\end{array}$ \\
\hline Parliamentary & 0.055 & & & & & & & & \\
\hline PolStab Aggr & -0.097 & 0.386 & & & & & & & \\
\hline PolStab Firm & 0.064 & 0.015 & 0.024 & & & & & & \\
\hline Medium size firm & -0.035 & -0.057 & -0.036 & 0.036 & & & & & \\
\hline Large size firm & -0.067 & -0.027 & 0.068 & 0.052 & -0.338 & & & & \\
\hline Influence Exec & 0.026 & 0.072 & 0.039 & 0.104 & 0.019 & 0.208 & & & \\
\hline Influence Leg & 0.029 & 0.089 & 0.078 & 0.118 & 0.025 & 0.197 & 0.769 & & \\
\hline Influence Min & 0.047 & 0.128 & 0.091 & 0.124 & 0.017 & 0.239 & 0.714 & 0.784 & \\
\hline Influence Reg Ag & 0.051 & 0.057 & 0.037 & 0.118 & 0.014 & 0.182 & 0.688 & 0.727 & 0.762 \\
\hline
\end{tabular}


Table 3

Determinants of Lobby Membership in 25 Transition Economies in 1999 Probit Estimates

\begin{tabular}{|c|c|c|c|c|c|c|}
\hline & (1) & $(2)$ & (3) & (4) & (5) & $(6)$ \\
\hline \multirow[t]{2}{*}{ Year firm started operate } & -0.003 & -0.004 & -0.004 & -0.004 & -0.004 & -0.004 \\
\hline & {$[0.001]^{*}$} & {$[0.001]^{* *}$} & {$[0.001]^{* *}$} & {$[0.001]^{* *}$} & {$[0.001]^{* *}$} & {$[0.001] * *$} \\
\hline \multirow[t]{2}{*}{ Medium size firm } & 0.262 & 0.327 & 0.342 & 0.342 & 0.328 & 0.324 \\
\hline & {$[0.061]^{* *}$} & {$[0.062]^{* *}$} & {$[0.063]^{* *}$} & {$[0.063]^{* *}$} & {$[0.062]^{* *}$} & {$[0.063]^{* *}$} \\
\hline \multirow[t]{2}{*}{ Large size firm } & 0.475 & 0.55 & 0.569 & 0.558 & 0.556 & 0.547 \\
\hline & {$[0.069]^{* *}$} & {$[0.072]^{* *}$} & {$[0.072]^{* *}$} & {$[0.072]^{* *}$} & {$[0.072]^{* *}$} & {$[0.072]^{* *}$} \\
\hline \multirow[t]{2}{*}{ Private owner } & -0.032 & 0.054 & 0.074 & 0.07 & 0.043 & 0.052 \\
\hline & {$[0.072]$} & {$[0.075]$} & {$[0.075]$} & {$[0.075]$} & {$[0.075]$} & [0.075] \\
\hline \multirow[t]{2}{*}{ Foreign owner } & 0.266 & 0.253 & 0.234 & 0.225 & 0.253 & 0.258 \\
\hline & {$[0.068]^{* *}$} & {$[0.070]^{* *}$} & {$[0.070]^{* *}$} & {$[0.070]^{* *}$} & {$[0.070]^{* *}$} & {$[0.070]^{* *}$} \\
\hline \multirow[t]{2}{*}{ Headquarter in capital } & 0.149 & 0.147 & 0.138 & 0.154 & 0.144 & 0.138 \\
\hline & {$[0.052]^{* *}$} & {$[0.053]^{* *}$} & {$[0.053]^{* *}$} & {$[0.053]^{* *}$} & {$[0.053]^{* *}$} & {$[0.053]^{* *}$} \\
\hline \multirow[t]{2}{*}{ Log per capita GDP } & 0.467 & 0.313 & 0.067 & 0.047 & 0.32 & 0.326 \\
\hline & {$[0.052]^{* *}$} & {$[0.058]^{* *}$} & {$[0.077]$} & {$[0.077]$} & {$[0.058]^{* *}$} & {$[0.059]^{* *}$} \\
\hline \multirow[t]{2}{*}{ Parliamentary system } & & 0.485 & 0.388 & 0.41 & 0.482 & 0.482 \\
\hline & & {$[0.059]^{* *}$} & {$[0.061]^{* *}$} & {$[0.062]^{* *}$} & {$[0.059]^{* *}$} & {$[0.059]^{* *}$} \\
\hline \multirow[t]{2}{*}{ Corruption (aggregate) } & & & -0.127 & -0.034 & & \\
\hline & & & {$[0.026]^{* *}$} & {$[0.037]$} & & \\
\hline Political Stability & & & & 0.242 & & \\
\hline (aggregate) & & & & {$[0.070]^{* *}$} & & \\
\hline \multirow[t]{2}{*}{ Corruption (firm-based) } & & & & & -0.098 & -0.099 \\
\hline & & & & & {$[0.049]^{*}$} & {$[0.049]^{*}$} \\
\hline Political Stability & & & & & & 0.119 \\
\hline (firm-based) & & & & & & {$[0.053]^{*}$} \\
\hline \multirow[t]{2}{*}{ Constant } & 0.758 & 3.396 & 5.912 & 5.502 & 3.506 & 3.236 \\
\hline & {$[2.670]$} & [2.840] & {$[2.897]^{*}$} & {$[2.906]$} & {$[2.852]$} & {$[2.850]$} \\
\hline Sector dummies? & Yes & Yes & Yes & Yes & Yes & Yes \\
\hline Log-likelihood & -1924.5 & -1821.5 & -1809.3 & -1803.7 & -1819.6 & -1816.6 \\
\hline Observations & 3847 & 3721 & 3721 & 3721 & 3721 & 3720 \\
\hline
\end{tabular}


Table 4a

The Determinants of Influence over Executive in 25 Transition Economies in 1999

\begin{tabular}{|l|c|c|c|c|}
\hline & $(1)$ & $(2)$ & $(3)$ & $(4)$ \\
\hline & Probit & Probit & IV Probit & IV Probit \\
\hline Lobby member & & & & \\
\hline & 0.466 & 0.453 & 1.744 & 1.445 \\
\hline Corruption (aggregate) & {$[0.061]^{* *}$} & {$[0.060]^{* *}$} & {$[.359]^{* *}$} & {$[.321]^{* *}$} \\
\hline & 0.012 & & .062 & \\
\hline Corruption & {$[0.038]$} & & {$[.044]$} & \\
\hline (firm-based) & & -0.085 & & -.037 \\
\hline Medium size firm & & {$[0.053]$} & & {$[.0545]$} \\
\hline & 0.272 & 0.265 & .127 & .169 \\
\hline Large size firm & {$[0.068]^{* *}$} & {$[0.068]^{* *}$} & {$[.086]$} & {$[.076]^{*}$} \\
\hline & 0.656 & 0.659 & .361 & .454 \\
\hline Private owner & {$[0.076]^{* *}$} & {$[0.076]^{* *}$} & {$[.146]^{*}$} & {$[.114]^{* *}$} \\
\hline & -0.296 & -0.286 & -.235 & -.236 \\
\hline Foreign owner & {$[0.074]^{* *}$} & {$[0.074]^{* *}$} & {$[.080]^{* *}$} & {$[.078]^{* *}$} \\
\hline & 0.205 & 0.207 & .113 & .131 \\
\hline Headquarter in capital & {$[0.077]^{* *}$} & {$[0.077]^{* *}$} & {$[.086]$} & {$[.084]$} \\
\hline & 0.015 & 0.001 & -.069 & -.065 \\
\hline Log per capita GDP & {$[0.059]$} & {$[0.058]$} & {$[.062]$} & {$[.063]$} \\
\hline & -0.17 & -0.153 & -.199 & -.332 \\
\hline Political Stability & {$[0.080]^{*}$} & {$[0.055]^{* *}$} & {$[.078]^{*}$} & {$[.069]^{* *}$} \\
\hline (aggregate) & 0.041 & & -.052 & \\
\hline Political Stability & {$[0.069]$} & & {$[.068]$} & \\
\hline (firm-based) & & 0.211 & & .1368025 \\
\hline Constant & & {$[0.057]^{* *}$} & & {$[.063]^{*}$} \\
\hline & 0.57 & 0.48 & .606 & 2.04 \\
\hline Sector dummies? & {$[0.802]$} & {$[0.478]$} & {$[.812]$} & {$[.625]^{* *}$} \\
\hline Observations & Yes & Yes & Yes & Yes \\
\hline Note: Hubes & 2908 & 2907 & 2791 & 2790 \\
\hline & & & & 2796 \\
\hline
\end{tabular}

Note: Huber-White standard errors (adjusted for heteroskedasticity of unknown form) in brackets; * significant at $5 \%$ level; ** significant at $1 \%$ level. First-stage regressions for columns (3) and (4) shown in table 3. 
Table $4 \mathrm{~b}$

The Determinants of Influence over Legislative in 25 Transition Economies in 1999

\begin{tabular}{|c|c|c|c|c|}
\hline & (1) & $(2)$ & (3) & (4) \\
\hline & Probit & Probit & IV Probit & IV Probit \\
\hline \multirow[t]{2}{*}{ Lobby member } & 0.506 & 0.49 & 1.501 & 1.181 \\
\hline & {$[0.060]^{* *}$} & {$[0.059]^{* *}$} & {$[.473]^{* *}$} & {$[.395]^{* *}$} \\
\hline \multirow[t]{2}{*}{ Corruption (aggregate) } & 0.016 & & .0547 & \\
\hline & {$[0.038]$} & & [.0458] & \\
\hline Corruption & & -0.046 & & -.019 \\
\hline (firm-based) & & {$[0.054]$} & & {$[.0558]$} \\
\hline \multirow[t]{2}{*}{ Medium size firm } & 0.244 & 0.234 & .143 & .175 \\
\hline & {$[0.068]^{* *}$} & {$[0.069] * *$} & [.093] & {$[.079]^{*}$} \\
\hline \multirow[t]{2}{*}{ Large size firm } & 0.572 & 0.57 & .367 & .443 \\
\hline & {$[0.076]^{* *}$} & {$[0.076]^{* *}$} & {$[.152]^{*}$} & {$[.116]^{* *}$} \\
\hline \multirow[t]{2}{*}{ Private owner } & -0.383 & -0.369 & -.328 & -.329 \\
\hline & {$[0.073]^{* *}$} & {$[0.073]^{* *}$} & {$[.084]^{* *}$} & {$[.079]^{* *}$} \\
\hline \multirow[t]{2}{*}{ Foreign owner } & 0.133 & 0.135 & .076 & .092 \\
\hline & {$[0.077]$} & {$[0.077]$} & [.0838] & [.082] \\
\hline \multirow[t]{2}{*}{ Headquarter in capital } & 0.045 & 0.026 & -.027 & -.022 \\
\hline & [0.059] & [0.058] & {$[.0707]$} & {$[.0676]$} \\
\hline \multirow[t]{2}{*}{ Log per capita GDP } & 0.045 & 0.037 & -.001 & -.095 \\
\hline & [0.080] & [0.055] & {$[.079]$} & [.089] \\
\hline Political Stability & 0.026 & & -.047 & \\
\hline (aggregate) & {$[0.070]$} & & {$[.074]$} & \\
\hline Political Stability & & 0.252 & & .197 \\
\hline (firm-based) & & {$[0.057]^{* *}$} & & {$[.065]^{* *}$} \\
\hline \multirow[t]{2}{*}{ Constant } & -1.301 & -1.172 & -1.08 & -.038 \\
\hline & [0.809] & {$[0.479]^{*}$} & [.809] & [.797] \\
\hline Sector dummies? & Yes & Yes & Yes & Yes \\
\hline Observations & 2924 & 2923 & 2806 & 2805 \\
\hline
\end{tabular}

Note: Huber-White standard errors (adjusted for heteroskedasticity of unknown form) in brackets; * significant at $5 \%$ level; ** significant at $1 \%$ level. First-stage regressions for columns (3) and (4) shown in table 3. 
Table 4c

The Determinants of Influence over Ministries in 25 Transition Economies in 1999

\begin{tabular}{|c|c|c|c|c|}
\hline & (1) & $(2)$ & (3) & (4) \\
\hline & Probit & Probit & IV Probit & IV Probit \\
\hline \multirow[t]{2}{*}{ Lobby member } & 0.484 & 0.478 & 1.76 & 1.58 \\
\hline & {$[0.059]^{* *}$} & {$[0.059]^{* *}$} & {$[.348]^{* *}$} & {$[.294]^{* *}$} \\
\hline \multirow[t]{2}{*}{ Corruption (aggregate) } & -0.043 & & .011 & \\
\hline & {$[0.038]$} & & {$[.044]$} & \\
\hline Corruption & & -0.065 & & .0008 \\
\hline (firm-based) & & {$[0.054]$} & & {$[.054]$} \\
\hline \multirow[t]{2}{*}{ Medium size firm } & 0.27 & 0.253 & .116 & .138 \\
\hline & {$[0.069]^{* *}$} & {$[0.069]^{* *}$} & {$[.086]$} & {$[.075]$} \\
\hline \multirow[t]{2}{*}{ Large size firm } & 0.705 & 0.693 & .393 & .445 \\
\hline & {$[0.076]^{* *}$} & {$[0.076]^{* *}$} & {$[.152]^{* *}$} & {$[.119]^{* *}$} \\
\hline \multirow[t]{2}{*}{ Private owner } & -0.314 & -0.309 & -.244 & -.235 \\
\hline & {$[0.073]^{* *}$} & {$[0.073]^{* *}$} & {$[.081]^{* *}$} & {$[.078]^{* *}$} \\
\hline \multirow[t]{2}{*}{ Foreign owner } & 0.142 & 0.145 & .069 & .0712 \\
\hline & {$[0.076]$} & [0.077] & [.079] & {$[.0786]$} \\
\hline \multirow[t]{2}{*}{ Headquarter in capital } & 0.09 & 0.086 & -.0006 & .0084 \\
\hline & [0.059] & {$[0.058]$} & {$[.066]$} & {$[.064]$} \\
\hline \multirow[t]{2}{*}{ Log per capita GDP } & -0.014 & 0.053 & -.069 & -.1612 \\
\hline & [0.081] & [0.055] & {$[.076]$} & {$[.079]^{*}$} \\
\hline Political Stability & -0.033 & & -.129 & \\
\hline (aggregate) & {$[0.071]$} & & {$[.07]$} & \\
\hline Political Stability & & 0.256 & & .166 \\
\hline (firm-based) & & {$[0.057]^{* *}$} & & {$[.064]^{* *}$} \\
\hline \multirow[t]{2}{*}{ Constant } & -0.692 & -1.503 & -.389 & .395 \\
\hline & [0.808] & {$[0.483]^{* *}$} & {$[.778]$} & {$[.734]$} \\
\hline Sector dummies? & Yes & Yes & Yes & Yes \\
\hline Observations & 2942 & 2941 & 2824 & 2823 \\
\hline
\end{tabular}

Note: Huber-White standard errors (adjusted for heteroskedasticity of unknown form) in brackets; * significant at 5\% level; ** significant at $1 \%$ level. First-stage regressions for columns (3) and (4) shown in table 3. 
Table 4d

The Determinants of Influence over Regulatory Agency in 25 Transition Economies in 1999

\begin{tabular}{|c|c|c|c|c|}
\hline & (1) & (2) & (3) & (4) \\
\hline & Probit & Probit & IV Probit & IV Probit \\
\hline \multirow[t]{2}{*}{ Lobby member } & 0.426 & 0.4 & .829 & .628 \\
\hline & {$[0.061]^{* *}$} & {$[0.061]^{* *}$} & {$[.494]^{*}$} & [.392] \\
\hline \multirow[t]{2}{*}{ Corruption (aggregate) } & 0.039 & & .021 & \\
\hline & {$[0.038]$} & & {$[.046]$} & \\
\hline Corruption & & -0.084 & & -.0603 \\
\hline (firm-based) & & {$[0.054]$} & & {$[.057]$} \\
\hline \multirow[t]{2}{*}{ Medium size firm } & 0.161 & 0.157 & .122 & .133 \\
\hline & {$[0.068]^{*}$} & {$[0.069]^{*}$} & [.0827] & {$[.075]$} \\
\hline \multirow[t]{2}{*}{ Large size firm } & 0.504 & 0.509 & .445 & .474 \\
\hline & {$[0.077]^{* *}$} & {$[0.077]^{* *}$} & {$[.117]^{* *}$} & {$[.099]^{* *}$} \\
\hline \multirow[t]{2}{*}{ Private owner } & -0.41 & -0.388 & -.398 & -.377 \\
\hline & {$[0.075]^{* *}$} & {$[0.075]^{* *}$} & {$[.077]^{* *}$} & {$[.077]$} \\
\hline \multirow[t]{2}{*}{ Foreign owner } & 0.142 & 0.138 & .127 & .129 \\
\hline & {$[0.077]$} & {$[0.077]$} & {$[.081]$} & {$[.08]$} \\
\hline \multirow[t]{2}{*}{ Headquarter in capital } & 0.098 & 0.074 & .085 & .076 \\
\hline & [0.059] & {$[0.058]$} & {$[.068]$} & {$[.065]$} \\
\hline \multirow[t]{2}{*}{ Log per capita GDP } & 0.033 & -0.022 & -.034 & -.100 \\
\hline & [0.078] & [0.055] & [.081] & {$[.08]$} \\
\hline Political Stability & 0.019 & & -.073 & \\
\hline (aggregate) & {$[0.070]$} & & {$[.077]$} & \\
\hline Political Stability & & 0.247 & & .225 \\
\hline (firm-based) & & {$[0.057]^{* *}$} & & {$[.062]^{* *}$} \\
\hline \multirow[t]{2}{*}{ Constant } & -1.195 & -0.525 & -.535 & .131 \\
\hline & {$[0.787]$} & [0.476] & [.839] & [.693] \\
\hline Sector dummies? & Yes & Yes & Yes & Yes \\
\hline Observations & 2807 & 2806 & 2690 & 2689 \\
\hline
\end{tabular}

Note: Huber-White standard errors (adjusted for heteroskedasticity of unknown form) in brackets; * significant at 5\% level; ** significant at 1\% level. First-stage regressions for columns (3) and (4) shown in table 3. 
Figure 1.

Lobby membership and log of per capita GDP: 25 Transition Economies, 1999

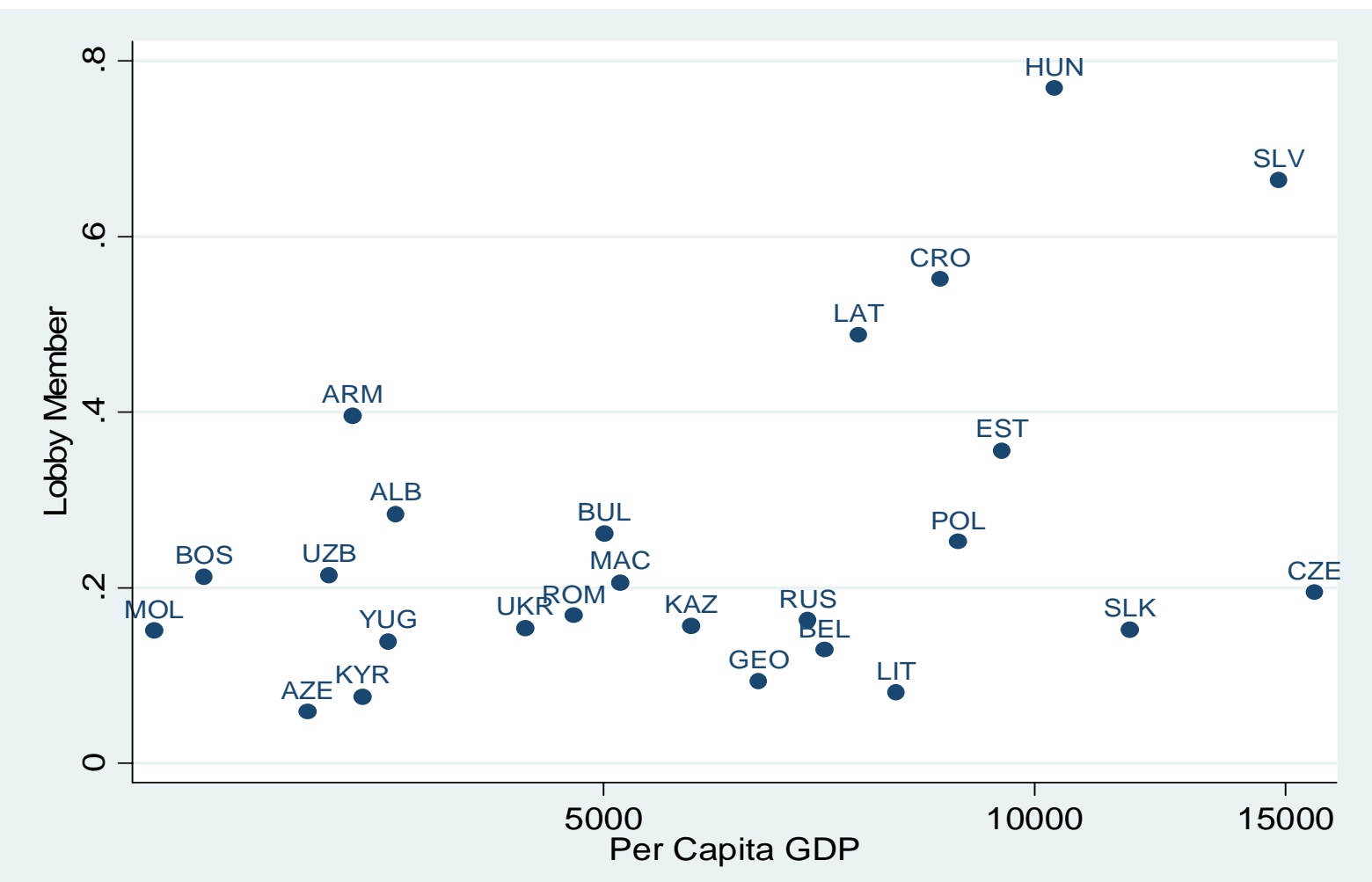

Figure 2.

Corruption (firm-based) and log of per capita GDP: 25 Transition Economies, 1999

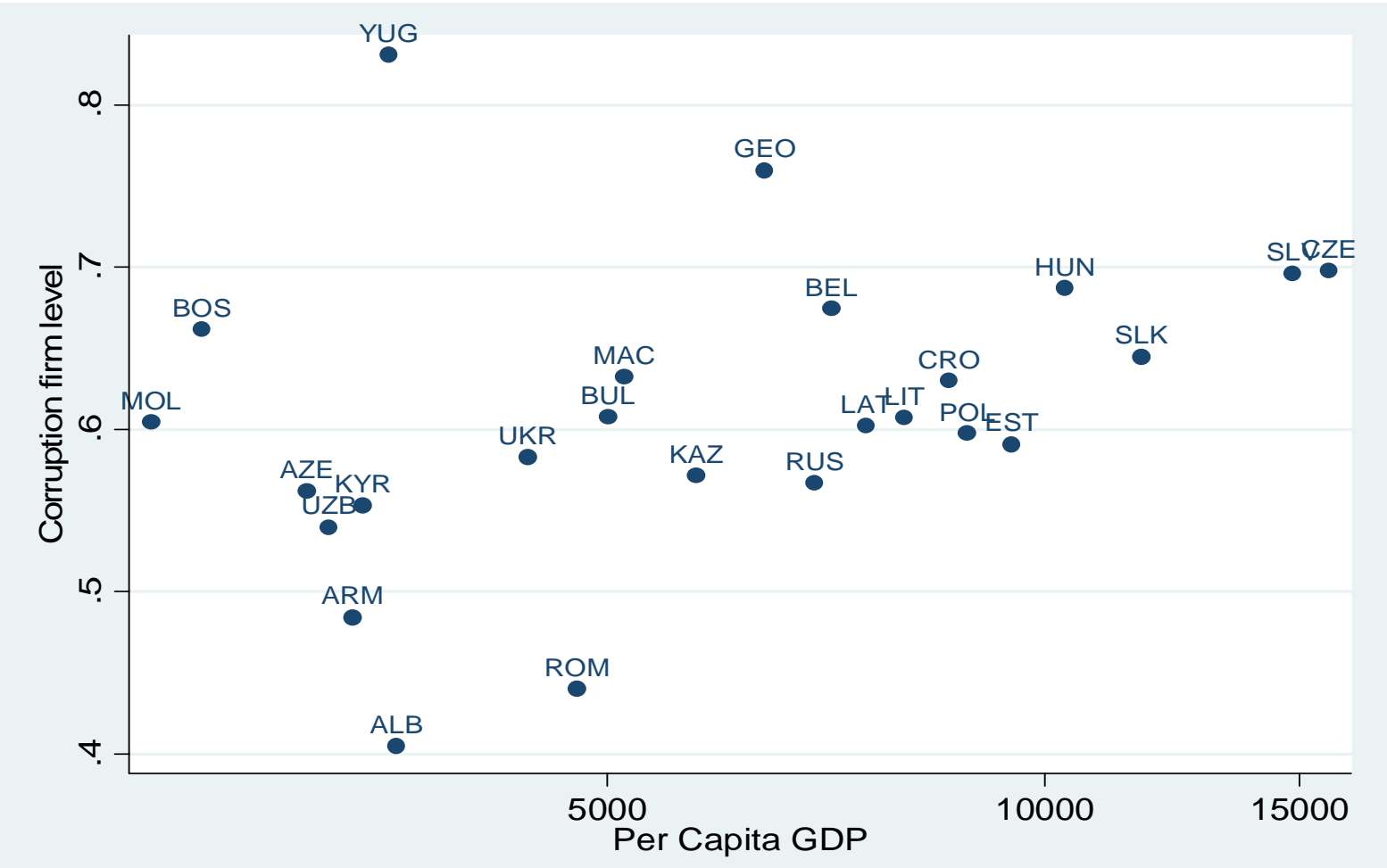


Figure 3.

Corruption (country-level) and log of per capita GDP: 25 Transition Economies, 1999

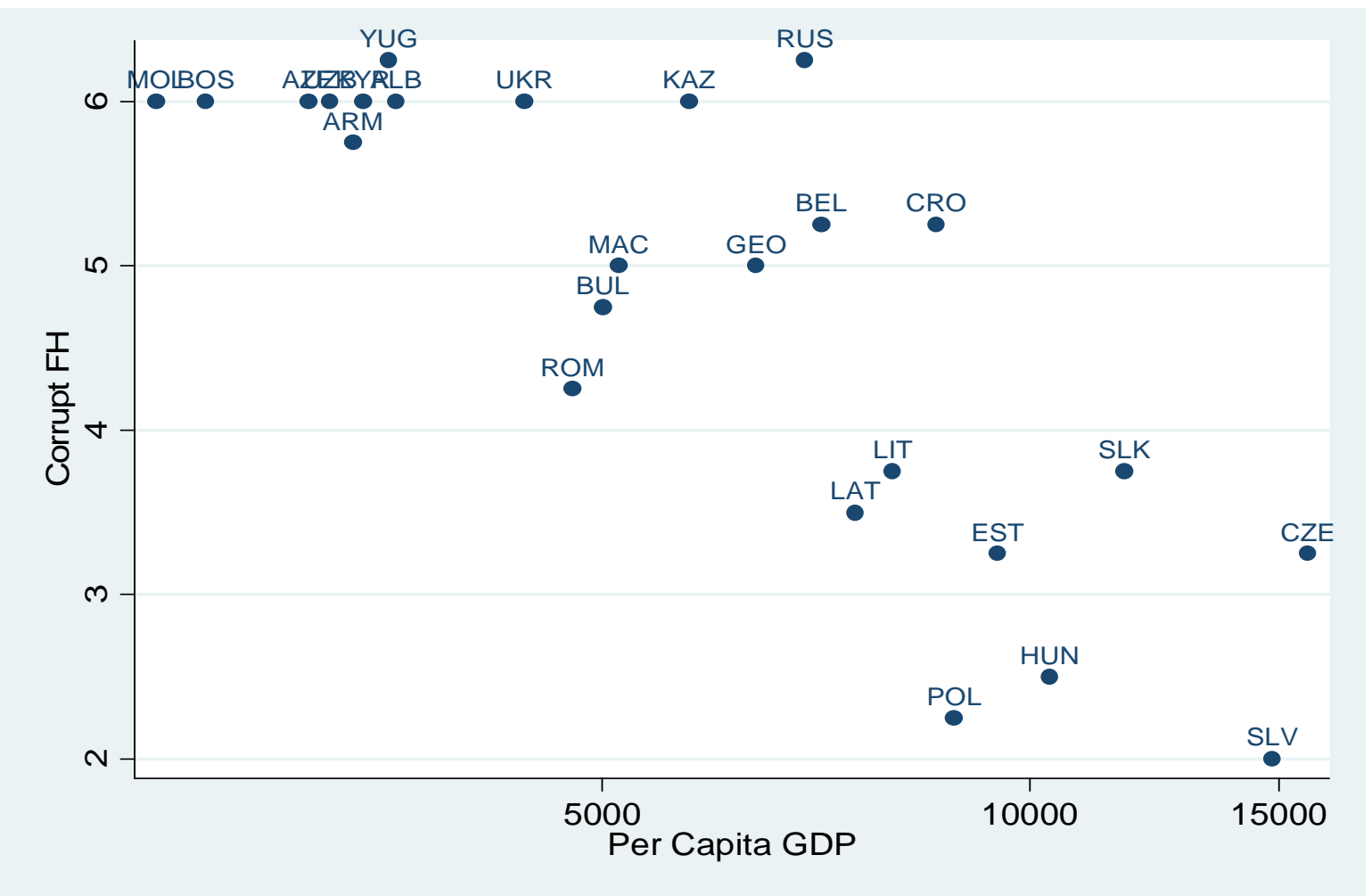

